------ Raf. Jou. Sci., Vol. 22, No.3 pp 62- 75, $2011------$

\title{
The Use of 3-Benzylidene Phthalide as Precursor to Synthesize New 1,3,4-Oxadiazole Derivatives
}

\author{
Shaymaa K. Younis \\ Department of Chemistry \\ College of Science \\ University of Mosul \\ Email :khazaalyounis@yahoo.com \\ (Received 1/11/2010; Accepted 25/4/2011)
}

\begin{abstract}
A series of new 2,5-disubstituted 1,3,4-oxadiazoles represented by compounds 2-phenyl-1(2-(5-(5-aryl-1,3,4-oxadiazol-2-yl amino)-4H-1,2,4-triazol-3-yl)phenyl)ethanone (5a-f) have been synthesized from(Z)-3-benzylidene phthalide as useful precursor. 3-Benzylidene phthalide was reacted, firstly with urea under microwave irradiation and dry conditions to afford the corresponding 1-(2-( $\alpha$-phenylacetyl)benzoyl)urea (1). The later compound underwent cycloaddition reaction with hydrazine hydrate $(80 \%)$ to give 1-(2-(5-amino-4H-1,2,4-triazol-3yl)phenyl)-2-phenylethanone (2), which upon reaction with ethyl chloroformate provided the corresponding ethyl- 5-(2-( $\alpha$-phenylacetyl)phenyl)-4H-1,2,4-triazol-3-yl carbamate (3).

4-(5-(2-( $\alpha$-Phenylacetyl)phenyl)-4H-1,2,4-triazol-3-yl) semicarbazide (4) was also prepared from the reaction of compound (3) with hydrazine hydrate $(80 \%)$ under mild conditions. Finally, 2-phenyl-1-(2-(5-(5-aryl-1,3,4-oxadiazol-2-yl amino)-4H-1,2,4-triazole-3-yl)phenyl) ethanone (5a-f) were obtained via the reaction of compound (4) with various substituted benzoic acid by the action of phosphorous oxychloride. The structure of the prepared compounds were confirmed by the available physical and spectral methods.
\end{abstract}

Key words: (Z)-3-benzylidene phthalide; 1,3,4-oxadiazole derivatives; 1,2,4-triazole; Semicarbazide. 


\section{المتخدلم 3 - بنزليليين فثاليدكماة الوليةمنالسبة لتحضير عددمن مركبلت 4,3,1 - الوكسادليازط الجيطة}

\section{|لمالخص}

حضرت سلسة جدية من مركبلت 4,3,1 -اوكسادايازول -5,2-ثنائي التعويض والمتمثلة بالمركبات 2 -

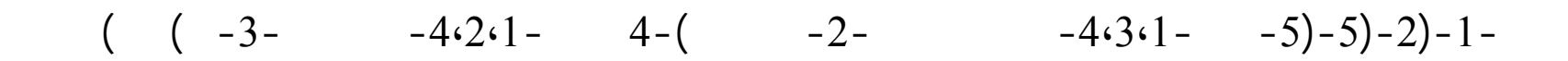
(5a-f)

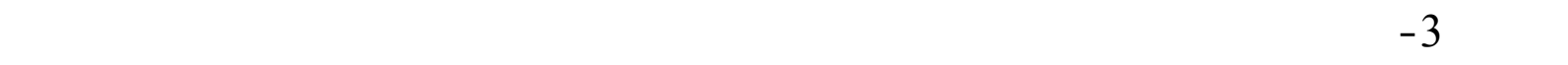

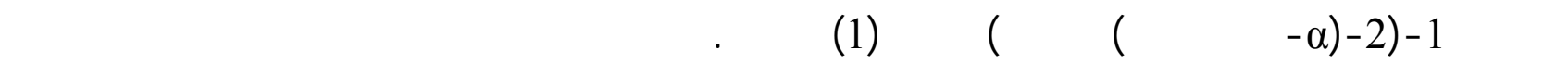

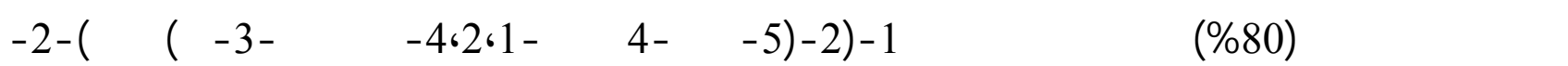

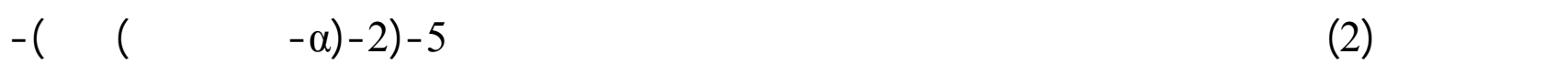

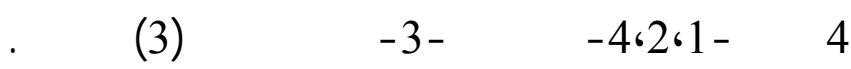

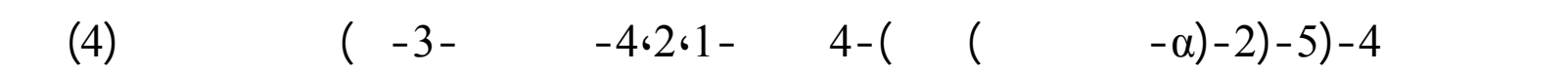

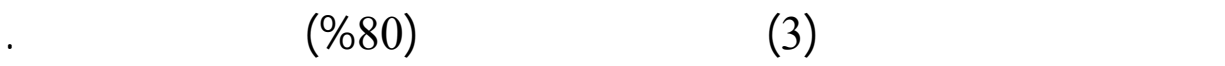

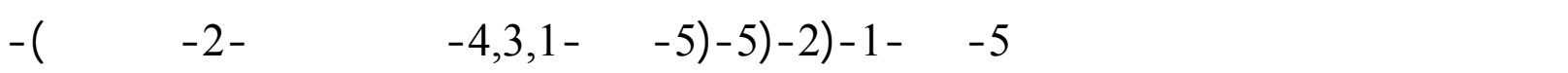

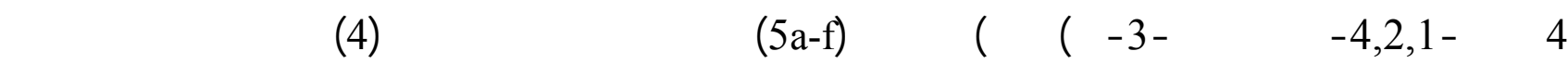
حلمض البززويك بوجود ثلاثي كلورو اوكسيد الفنفور.شخصت جميع المركبلت المحضرة بلستخدلم الطرائق الفيزياوية والطيفية المتوفرة.

\section{INTRODUCTION}

Heterocyclic compounds have a great deal of attention because of their biological activity and also they make possible development of novel material with unique properties (Mostafa, 2010; Arulmurugan and Kavitha, 2010; Srinivas and Kumar, 2010; Caiazzo et al, 2004). One very interesting and promising class of heterocyclic is the series of 2,5-disubstituted-1,3,4oxadiazoles that have been proven to be effective antimicrobial, anti-inflammatory, fungicidal and bactericidal agents (Sharma et al., 2010; Narasimhan et al.,2010; Banday et al., 2010; Dewangan et al., 2010; Bari et al., 2008 ). Furthermore, the 1,3,4-oxadiazole nucleus is associated with divers pharmaceutical activities as antitumor, antitubercular, antimalariea and analagesic (Revanasiddappa and Subrahmanyam, 2010; Patel and Patel, 2010; Mitsui and Aoki, 2010; Husain and Ajmal, 2009; He et al., 2009). On the other hand, these compounds have 
been extensively employed in industrial and agrecultural field (Naik et al., 2009; Jain et al., 2009; Kim and Kang, 2008; Awadallah, 2006).

In this presentation, (Z)-3-benzylidene phthalide which is another type of heterocyclic was used as useful precursor to obtaind 1,3,4-oxadiazoles. Optionally, 3-substituted phthalides have wide applications in idusterial field (Shibata and Gaesser, 1991; Scholl et al., 1989; Conner, 1982) and also have emerged as inexpensive and easily available reagents in organic synthesis (Dalloul, 2010; Viña et al., 2009; del Olmo et al., 2006; Rios and Delgado, 1999; Hrnčiar et al., 1994; Humber, 1974; Rosenthal and Yalpani, 1965; Litvan and Stoll, 1958). Moreover, these compounds are known to possess multiple biological activities (Kurume et al., 2008; Kanazawa and Terada, 2007; Kundu et al., 1998; Ganji et al., 1993; Ibrahim, 1991). Several 3-substituted phthalides have been isolated from natural source and also used extensively as intermediat for the synthesis of varous drugs and naturally occuring compounds (Tang et al., 2010; Phan et al., 2009; Patil and Karnik, 2007).

In this resaerch, it is planned to generate a new series of 2,5-disubstituted-1,3,4oxadiazoles represented by compounds (5a-f), (Z)-3-benzylidene phthalide firstly was reacted with urea to prepar compound (1) and the latter will be used as key intermediat to synthesize 1,2,4-triazole represented by compound (2) which was in turn used as useful material to prepar 1,3,4-oxadiazoles compounds (5a-f).

\section{EXPERIMENTAL}

Melting points (M.P.) were measured on Electrothermal, Gallenkamp melting point apparatus and are uncorrected. Proton-Nuclear Magnetic Resonance $\left({ }^{1} \mathrm{H}-\mathrm{NMR}\right)$ spectra were recorded using, spectrophotometer $(\mathrm{H} 300 \mathrm{MHz})$; with TMS as internal standard, and DMSO- $\mathrm{d}_{6}$ as solvents; Jorden, University of Al-Bayt. [(s) singlet; (t) triplet; (q) quarlet; (m) multiplet].Infrared (FT-IR) spectra were recorded as $(\mathrm{KBr})$ disc using FT-IR-600, Biotech Engineering Mangement CO. LTD. (UK ). Ultraviolet (UV) spectra were performed on Shimadzu UV-Visible spectrophotometer UV-1650 PC using methanol as a solvent. The microwave oven is a domestic microwave oven (LG, MS-192W), (360watt) was used. The starting material (Z)-3-benzylidene phthalide was manufactured via Fluka Com. (Germany). Finally, thin layer chromatography (TLC) were carried out on silica gel (120 mesh) coated plates $(2 \times 10) \mathrm{cm}$, activated for one hour at $\left(110-120^{\circ} \mathrm{C}\right)$ before use.

\section{Synthesis of 1-(2-( $\alpha$-phenylacetyl)benzoyl)urea (1): (Ilango et al, 2010; Benjamin and Hijji, 2007)}

A mixture of (Z)-3- benzylidene phthalide (0.01 mole, $2.22 \mathrm{gm})$ and urea (0.01mole, 0.6 $\mathrm{gm})$ was irradiated in microwave oven for $(4 \mathrm{~min}$.) at (360 watt). The reaction mixture was cooled down to room temperature, water was added and the mixture was washed thoroughly with water. The crude product was purified by recrystallization from methanol to yield compound (1) (1.9 gm), m.p. $\left(79-80^{\circ} \mathrm{C}\right)$ in $(72 \%)$ yield. The purity of the obtained product was controlled by TLC technique using solvent system (ethyl acetate: acetone) in $(9: 1)$ ratio, $\mathrm{R}_{\mathrm{f}}$ value (0.451), $\mathrm{H}^{1}$-NMR (DMSO-d6) $\delta$ /ppm: $3.5\left(\mathrm{~s}, 2 \mathrm{H}, \mathrm{CH}_{2}\right), 6.7\left(\mathrm{~s}, 2 \mathrm{H}, \mathrm{NH}_{2}\right), 7.1-8.2(\mathrm{~m}, \mathrm{H}-$ 
aromatic) and $10.7(\mathrm{~s}, 1 \mathrm{H}, \mathrm{NH}), \mathrm{FT}-\mathrm{IR}(\mathrm{KBr}) v / \mathrm{cm}^{-1}: 3205\left(\mathrm{NH}_{2}\right), 1677(\mathrm{C}=\mathrm{O}$ ketone $)$ and 1657 ( $\mathrm{C}=\mathrm{O}$ amide), $\mathrm{UV}$ (methanol) $\lambda_{\max }: 226 \mathrm{~nm}$.

\section{Synthesis of 1-(2-(5-amino-4H-1,2,4-triazol-3-yl)phenyl)-2-phenylethanone (2): (Şener, 2004)}

Excess of hydrazine hydrate $(80 \%)(0.08$ mole, $4 \mathrm{ml})$ was added to compound (1) $(0.007$ mole, $1.96 \mathrm{gm})$ in ethanol $(30 \mathrm{ml})$ with a catalytic amount of triethyl amine $(1 \mathrm{ml})$. The reaction mixture was heated under reflux for $(4 \mathrm{hrs}$.) with stirring and was then left to cool at room temperature. The precipitate that formed was filtered off, dried and recrstallized from ethanol to give compound (2) (1.85 gm), m.p. $\left(192-193^{\circ} \mathrm{C}\right)$ in $(96 \%)$ yield. The purity of the obtained product was controlled by TLC technique using solvent system (ethyl acetate: acetone) in (9:1) ratio, $\mathrm{R}_{\mathrm{f}}$ value (0.731), $\mathrm{H}^{1}$-NMR (DMSO-d6) $\delta / \mathrm{ppm}: 3.4\left(\mathrm{~s}, 2 \mathrm{H}, \mathrm{CH}_{2}\right), 4.3\left(\mathrm{~s}, 1 \mathrm{H}, \mathrm{NH}_{2}\right), 7.1-8.2$ (m,H-aromatic) and $13\left(\mathrm{~s}, 1 \mathrm{H}, \mathrm{NH}\right.$-triazole), FT-IR (KBr) v / $\mathrm{cm}^{-1}: 3302\left(\mathrm{NH}_{2}\right), 3193(\mathrm{NH})$, $1658(\mathrm{C}=\mathrm{O})$ and $1608(\mathrm{C}=\mathrm{N}), \mathrm{UV}$ (methanol) $\lambda_{\max }: 290$ and $254 \mathrm{~nm}$.

\section{Synthesis of ethyl 5-(2-( $\alpha-$ phenylacetyl)phenyl)-4H-1,2,4-triazol-3-yl carbamate (3): (Aly and EL-Sayed, 2006)}

Ethyl chloroformate $(0.023$ mole, $2.2 \mathrm{ml})$ was added dropwise to a solution of compound (2) $(0.023$ mole, $6 \mathrm{gm})$ in pyridine $(15 \mathrm{ml})$. The reaction mixture was stirred at room temperature for $(1 \mathrm{hr}$.$) , it was then poured on (100 \mathrm{ml})$ ice-water and the precipitated carbamate was filtered off, washed thoroughly with water, dilute hydrochloric acid then water again and recrystallized from ethanol to afford compound (3), $(4.6 \mathrm{gm})$, m.p. $\left(148-150^{\circ} \mathrm{C}\right)$ in $(61 \%)$ yield. The purity of the obtained product was controlled by TLC technique using solvent system (ethyl acetate: acetone) in $(9: 1)$ ratio, $\mathrm{R}_{\mathrm{f}}$ value $(0.773), \mathrm{H}^{1}$-NMR (DMSO-d6) $\delta / \mathrm{ppm}: 1.4$ $\left(\mathrm{t}, 3 \mathrm{H}, \mathrm{CH}_{3}\right), 3.4\left(\mathrm{~s}, 2 \mathrm{H}, \mathrm{CH}_{2}\right), 4.5\left(\mathrm{q}, 2 \mathrm{H}, \mathrm{O}-\mathrm{CH}_{2}\right), 7.1-8.3(\mathrm{~m}, \mathrm{H}$-aromatic $), 8.4(\mathrm{~s}, 1 \mathrm{H}, \mathrm{NH})$ and 13 (NH-triazole), FT-IR (KBr) v / $\mathrm{cm}^{-1}: 3159(\mathrm{NH}), 1763(\mathrm{C}=\mathrm{O}$ urethane), $1658(\mathrm{C}=\mathrm{O}$ ketone) and $1608(\mathrm{C}=\mathrm{N}), \mathrm{UV}$ (methanol) $\lambda_{\max }: 238$ and $282 \mathrm{~nm}$.

\section{Synthesis of 4-(5-(2-( $\alpha$-phenylacetyl)phenyl)-4H-1,2,4-triazol-3-yl) semicarbazide}

(4): (Mayekar, 2010)

A mixture of appropriate carbamate (3) (0.01 mole, $3.32 \mathrm{gm})$ and excess of hydrazine hydrate $(80 \%)(0.08$ mole, $4 \mathrm{ml})$ in ethanol $(30 \mathrm{ml})$ with a catalytic amount of triethyl amine ( $1 \mathrm{ml})$. The reaction mixture was stirred for $(3 \mathrm{hrs}$.) then poured on ice-water and acidified with diluted hydrochloric acid. The precipitate that formed was filtered off, washed thoroughly with water, dried to give compound (4) $(2.9 \mathrm{gm})$, m.p. $\left(194-196^{\circ} \mathrm{C}\right)$ in $(91 \%)$ yield. The purity of the obtained product was controlled by TLC technique using solvent system (ethyl acetate: acetone) in (9:1) ratio, $\mathrm{R}_{\mathrm{f}}$ value (0.714), $\mathrm{H}^{1}-\mathrm{NMR}$ (DMSO-d6) $\delta / \mathrm{ppm}: 3.4\left(\mathrm{~s}, \mathrm{H}, \mathrm{NH}_{2}\right), 4.3$ $\left(\mathrm{s}, 2 \mathrm{H}, \mathrm{CH}_{2}\right), 6.9$ (s,1H,NH-urea), 7.1-8.2(m,H-aromatic) and 13.2 (s,1H,NH-triazole), FT-IR $(\mathrm{KBr}) v / \mathrm{cm}^{-1}$ : $3300\left(\mathrm{NH}_{2}\right), 3159(\mathrm{NH}), 1690(\mathrm{C}=\mathrm{O}$ ketone $), 1658(\mathrm{C}=\mathrm{O}$ amide $)$ and 1608 $(\mathrm{C}=\mathrm{N})$, UV (methanol) $\lambda_{\max }: 246$ and $274 \mathrm{~nm}$. 
Synthesis of 2-phenyl-1-(2-(5-(5-aryl-1,3,4-oxadiazol-2-ylamino)-4H-1,2,4-triazol-3yl)phenyl)ethanone (5a-f): (Revanasiddappa and Subrahmanyam, 2010)

A mixture of compound (4) (0.0005 mole, $0.16 \mathrm{gm})$, substituted benzoic acid $(0.0005$ mole) and phosphorous oxychloride $(3 \mathrm{ml})$ was refluxed for $(4 \mathrm{hrs}$.). The contents were cooled to room temperature and poured onto crushed ice. It was then neutralized by adding sodium bicarbonate. The solid product was collected by filtration then dried. Further purification was done by recrystallization from a mixture of methanol-water to yield the desired oxadiazoles (5a-f). The purity of the obtained product was controlled by TLC technique using solvent system (ethyl acetate: acetone) in (9:1) ratio. The physical and spectral data were listed in Table (1) and (2).

Table 1: Physical properties and spectral data for compounds (5a-f).

\begin{tabular}{|c|c|c|c|c|c|c|c|c|c|c|}
\hline \multirow{2}{*}{$\begin{array}{c}\text { Comp. } \\
\text { No. }\end{array}$} & \multirow[b]{2}{*}{$\mathbf{X}$} & \multirow{2}{*}{$\begin{array}{l}\text { M.P. } \\
\left({ }^{\circ} \mathbf{C}\right)\end{array}$} & \multirow{2}{*}{$\begin{array}{c}\text { Yield } \\
(\%)\end{array}$} & \multirow{2}{*}{$\begin{array}{c}\mathbf{R}_{\mathbf{f}} \\
\text { Value }\end{array}$} & \multirow{2}{*}{$\begin{array}{c}\text { UV } \\
(\mathrm{MeOH}) \\
\lambda_{\max }(\mathrm{nm})\end{array}$} & \multicolumn{5}{|c|}{$\operatorname{IR}(\mathrm{KBr}) v\left(\mathrm{~cm}^{-1}\right)$} \\
\hline & & & & & & NH & $\mathbf{C}=\mathbf{O}$ & $\mathbf{C}=\mathbf{N}$ & $\begin{array}{l}\text { C-O-C } \\
\text { (cyclic) }\end{array}$ & others \\
\hline $5 a$ & $\mathrm{H}$ & $140-142$ & 65 & 0.487 & 280 & 3162 & 1660 & 1599 & 1169 & - \\
\hline $5 b$ & $\mathrm{o}-\mathrm{Cl}$ & $127-129$ & 62 & 0.407 & 278 & 3170 & 1655 & 1591 & 1174 & - \\
\hline $5 \mathrm{c}$ & 2,4-diCl & 98-101 & 68 & 0.438 & 280 & 3161 & 1658 & 1608 & 1180 & - \\
\hline $5 d$ & $\mathrm{o}-\mathrm{NO}_{2}$ & $206-208$ & 81 & 0.628 & 274 & 3171 & 1664 & 1604 & 1166 & $\begin{array}{c}\mathrm{NO}_{2} \\
\text { asym } 1545 \\
\text { sym } 1321\end{array}$ \\
\hline $5 e$ & $\mathrm{~m}-\mathrm{NO}_{2}$ & $140-141$ & 72 & 0.608 & 278 & 3163 & 1658 & 1608 & 1173 & $\begin{array}{c}\mathrm{NO}_{2} \\
\text { asym } 1535 \\
\text { sym } 1392\end{array}$ \\
\hline $5 f$ & $\mathrm{p}-\mathrm{NO}_{2}$ & $122-123$ & 67 & 0.452 & 282 & 3163 & 1660 & 1601 & 1174 & $\begin{array}{c}\mathrm{NO}_{2} \\
\text { asym } 1522 \\
\text { sym } 1390\end{array}$ \\
\hline
\end{tabular}


Table 2: The $\mathrm{H}^{1}$-NMR spectral data for compounds (5a-c and 5e-f).

\begin{tabular}{|c|c|c|}
\hline $\begin{array}{c}\text { Comp. } \\
\text { No. }\end{array}$ & $\mathbf{X}$ & $\mathbf{H}^{1}$-NMR (DMSO-d 6 ) $\delta(\mathbf{p p m})$ \\
\hline $5 \mathrm{a}$ & $\mathrm{H}$ & $4.4\left(\mathrm{~s}, 2 \mathrm{H}, \mathrm{CH}_{z}\right), 4.9(\mathrm{~s}, 1 \mathrm{H}, \mathrm{NH}), 7.1-8.5(\mathrm{~m}, \mathrm{H}$-aromatic $)$ and $13.2(\mathrm{~s}, 1 \mathrm{H}, \mathrm{NH}$-triazole $)$ \\
\hline $5 b$ & $\mathrm{o}-\mathrm{Cl}$ & $3.4\left(\mathrm{~s}, 2 \mathrm{H}, \mathrm{CH}_{2}\right), 4.8(\mathrm{~s}, 1 \mathrm{H}, \mathrm{NH}), 7.1-8.4(\mathrm{~m}, \mathrm{H}$-aromatic $)$ and $13.0(\mathrm{~s}, 1 \mathrm{H}, \mathrm{NH}$-triazole \\
\hline $5 \mathrm{c}$ & 2,4-diCl & $4.2\left(\mathrm{~s}, 2 \mathrm{H}, \mathrm{CH}_{2}\right), 4.7(\mathrm{~s}, 1 \mathrm{H}, \mathrm{NH}), 7.2-8.4(\mathrm{~m}, \mathrm{H}$-aromatic $)$ and $12.9(\mathrm{~s}, 1 \mathrm{H}, \mathrm{NH}$-triazole \\
\hline $5 \mathrm{e}$ & $\mathrm{m}-\mathrm{NO}_{2}$ & $3.9\left(\mathrm{~s}, 2 \mathrm{H}, \mathrm{CH}_{z}\right), 4.9(\mathrm{~s}, 1 \mathrm{H}, \mathrm{NH}), 7.2-8.6(\mathrm{~m}, \mathrm{H}$-aromatic $)$ and $12.8(\mathrm{~s}, 1 \mathrm{H}, \mathrm{NH}$-triazole \\
\hline $5 f$ & $\mathrm{p}-\mathrm{NO}_{2}$ & $3.8\left(\mathrm{~s}, 2 \mathrm{H}, \mathrm{CH}_{z}\right), 4.7(\mathrm{~s}, 1 \mathrm{H}, \mathrm{NH}), 7.2-8.4(\mathrm{~m}, \mathrm{H}$-aromatic $)$ and $12.9(\mathrm{~s}, 1 \mathrm{H}, \mathrm{NH}$-triazole \\
\hline
\end{tabular}

\section{RESULTS AND DISCUSSION}

The synthetic path way leading to the title compounds is given in scheme (1).

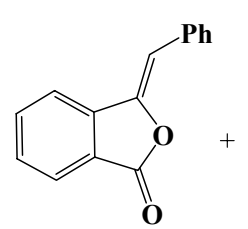

3-Benzylidene phthalide

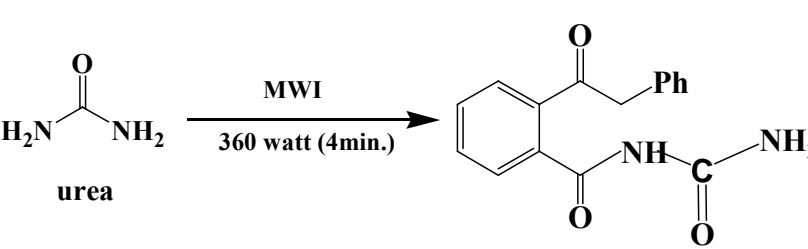

(1)

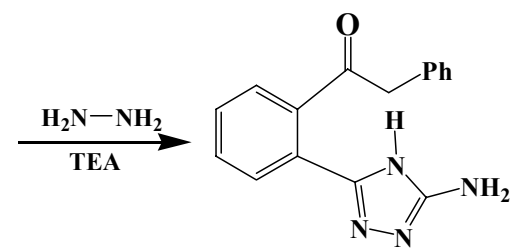

(2) $\downarrow^{\mathrm{Cl}^{-1}} \mathrm{O}^{-\mathrm{Et}}$

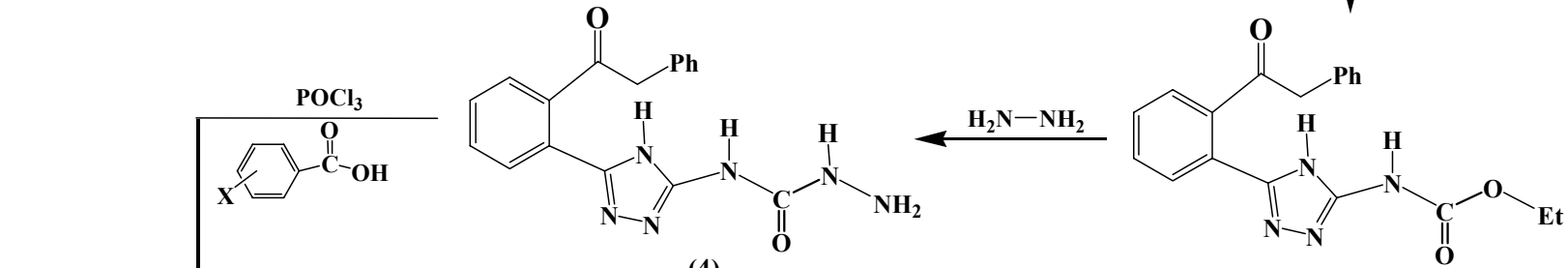

(4)

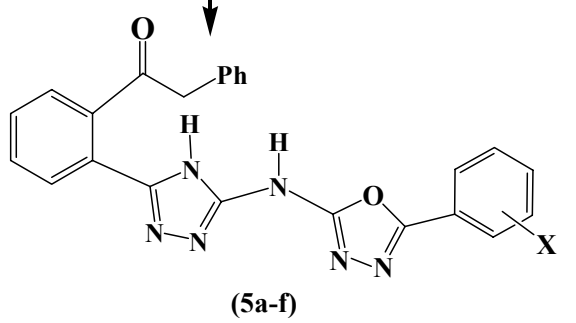


The synthesis of 2-phenyl-1-(2-(5-(5-aryl-1,3,4-oxadiazol-2-yl amino)-4H-1,2,4-triazol-3yl)phenyl)ethanone (5a-f) required in the first step preparation of the starting material, namely 1-(2-( $\alpha$-phenylacetyl)benzoyl) urea (1) which was prepared from the direct reaction between (Z)-3-benzylidene phthalide as a useful precursor and urea. This reaction was found to proceed smoothly under microwave irradiation in dry conditions within (4 min.) at (360 watt) (equation 1), the proposed mechanism was summarized in scheme (2) (Chiriac et al., 2007; Youssef, 2006).

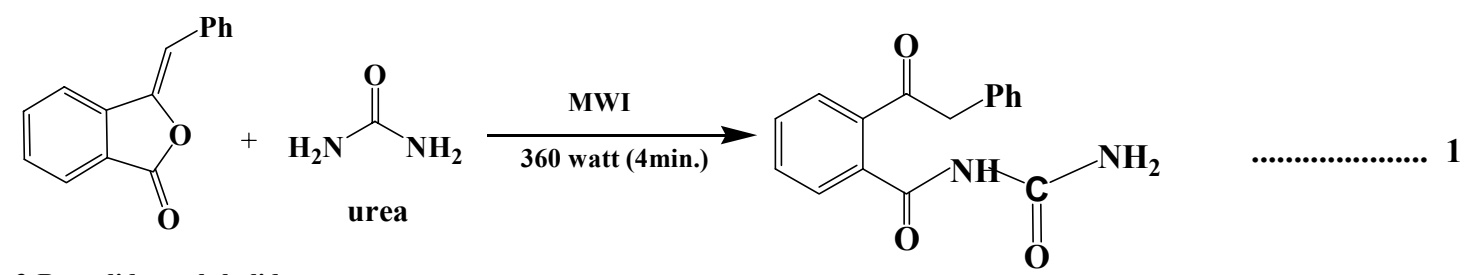

3-Benzylidene phthalide

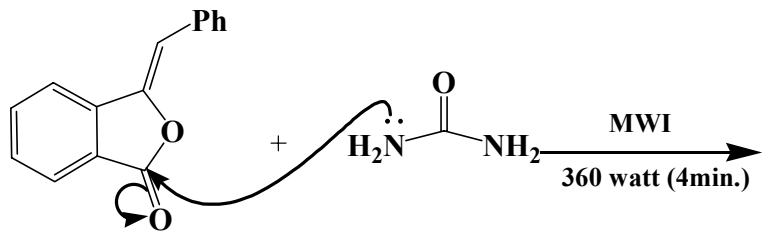

3-benzylidene phthalide

(1)<smiles>CC(C(=O)c1ccccc1C(=O)NC(N)=O)c1ccc(C(=O)NC(N)=O)c(C(O)=Cc2ccccc2)c1</smiles>

(1)

\section{Scheme (2)}

The structure of the later compound was established on the bases of the presence of an $\left(\mathrm{NH}_{2}\right)$ and $(\mathrm{NH})$ absorption bands in the $\left(3205 \mathrm{~cm}^{-1}\right)$ and $\left(3163 \mathrm{~cm}^{-1}\right)$ region, $(\mathrm{C}=\mathrm{O})$ ketone and amide absorption bands at $\left(1677 \mathrm{~cm}^{-1}\right)$ and $\left(1657 \mathrm{~cm}^{-1}\right)$ region respectively in it's IR spectrum, whereas it's UV spectrum revealed the presence of absorption band at $\lambda_{\max }(226 \mathrm{~nm})$ due to the conjugation, (Finar, 1977; Parikh, 1974). Further structure proof of compound (1) has came from ${ }^{1} \mathrm{H}-\mathrm{NMR}$ spectra which showed significant peaks at $\delta(\mathrm{ppm}): 3.5\left(\mathrm{~s}, 2 \mathrm{H}, \mathrm{CH}_{2}\right), 6.7$ $\left(\mathrm{s}, 2 \mathrm{H}, \mathrm{NH}_{2}\right), 7.1-8.2(\mathrm{~m}, \mathrm{H}$-aromatic) and $10.67(\mathrm{~s}, 1 \mathrm{H}, \mathrm{NH})$.

Compound (1) reacted with hydrazine hydrate $(80 \%)$ through cycloaddition reaction in refluxed ethanol to obtaine compound (2) represented by 1-(2-(5-amino-4H-1,2,4-triazol-3yl)phenyl)-2-phenylethanone. The mechanism of this reaction proceed through an ordinary 
nucleophilic attack of hydrazine hydrate the amide carbonyl carbon to afford the intermediat (I) which in turn loses a molecule of water to give the condensed intermediat (II). The other $\mathrm{NH}_{2}$ group of hydrazine will attack the other amide carbonyl carbon then the intramolecular cycloaddition reaction will occure to form compound (2). The mechanism of formation of compound (2) is outlined in scheme (3) (Aly et al., 2009; Shetgiri and Nayak, 2005; AlMousawi and El-Apasery, 2009).

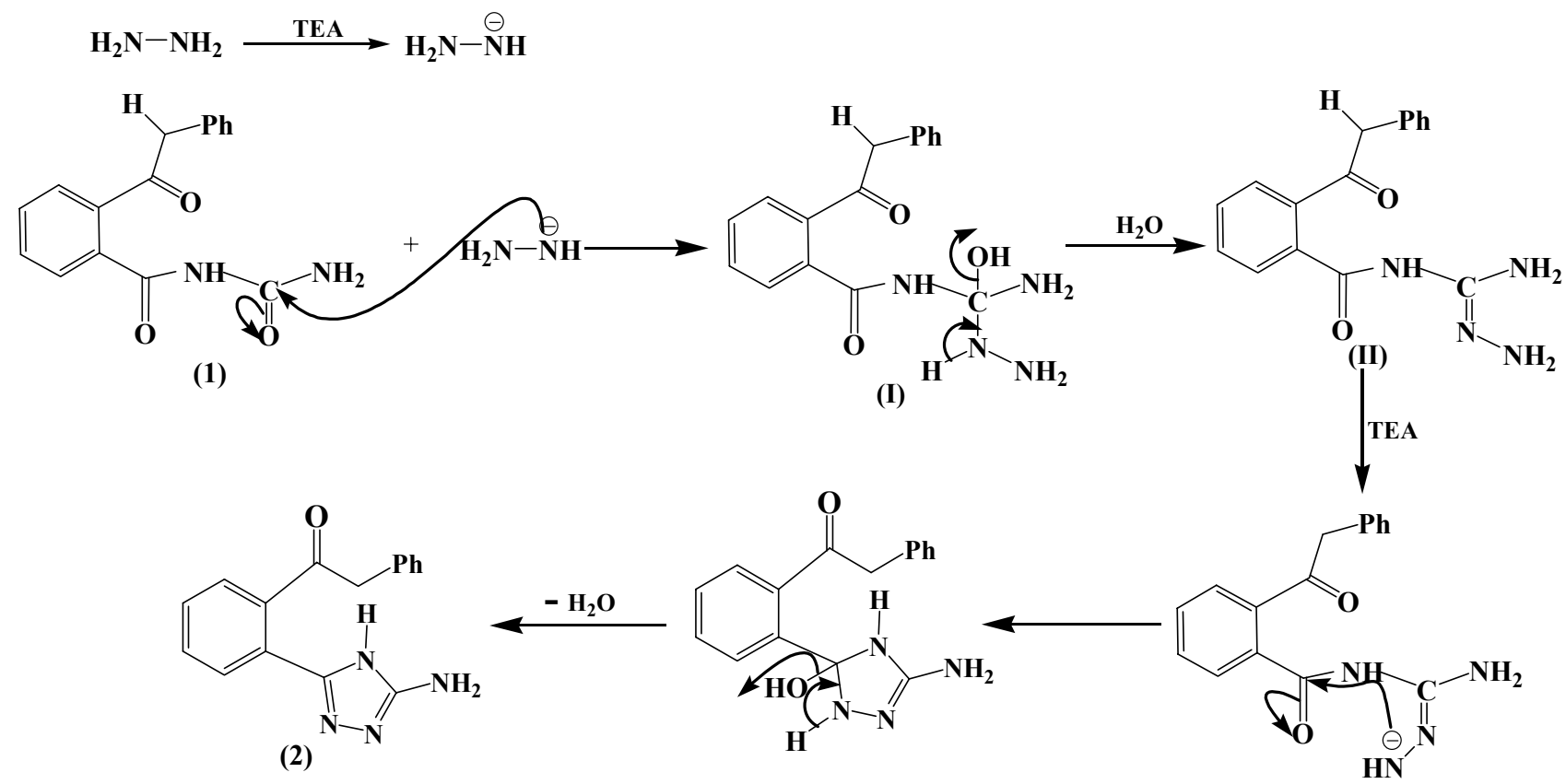

\section{Scheme (3)}

The structure of compound (2) was confirmed by IR and UV spectra. The IR spectrum shows a characteristic absorption band at: $\left(3302 \mathrm{~cm}^{-1}\right)$ corresponding to $\left(\mathrm{NH}_{2}\right)$ functional group, $\left(3193 \mathrm{~cm}^{-1}\right)$ corresponding to $(\mathrm{NH})$ functional group, $\left(1658 \mathrm{~cm}^{-1}\right)$ releated to $(\mathrm{C}=\mathrm{O})$ functional group and $\left(1608 \mathrm{~cm}^{-1}\right)$ assigned to $(\mathrm{C}=\mathrm{N})$ functional group. The absence of both $(\mathrm{C}=\mathrm{O})$ of amide gave an evidence for the formation of compound (2), while it's UV spectrum showed absorption band at $\lambda_{\max }(290 \mathrm{~nm})$ and $(254 \mathrm{~nm})$ due to the increasing of ring system and also to $\pi \rightarrow \pi^{*}$ and $n \rightarrow \pi^{*}$ transition respectively, (Finar, 1977; Parikh, 1974). On the other hand, the structure of compound (2) was confirmed by ${ }^{1} \mathrm{H}-\mathrm{NMR}$ spectra which showed significant peaks at $\delta(\mathrm{ppm}): 3.4\left(\mathrm{~s}, 2 \mathrm{H}, \mathrm{CH}_{2}\right), 4.3\left(\mathrm{~s}, 2 \mathrm{H}, \mathrm{NH}_{2}\right), 7.5-8.2(\mathrm{~m}, \mathrm{H}$-aromatic $)$ and $13.0(\mathrm{~s}, 1 \mathrm{H}, \mathrm{NH}-$ triazole).

Compound (2) was also underwent nucleophilic substitution reaction with ethyl chloroformate to afford the corresponding ethyl 5-(2-( $\alpha$-phenylacetyl $)$ phenyl)-4H-1,2,4-triazol3 -yl carbamate (3), which in turn reacted with hydrazine hydrate to give the corresponding 
4-(5-(2-( $\alpha$-phenylacetyl)phenyl)-4H-1,2,4-triazol-3-yl)semicarbazide (4), Scheme (4) outlined the synthesis of compounds (3) and (4) respectively, (Demirbas et al., 2005; Loudon, 2002).

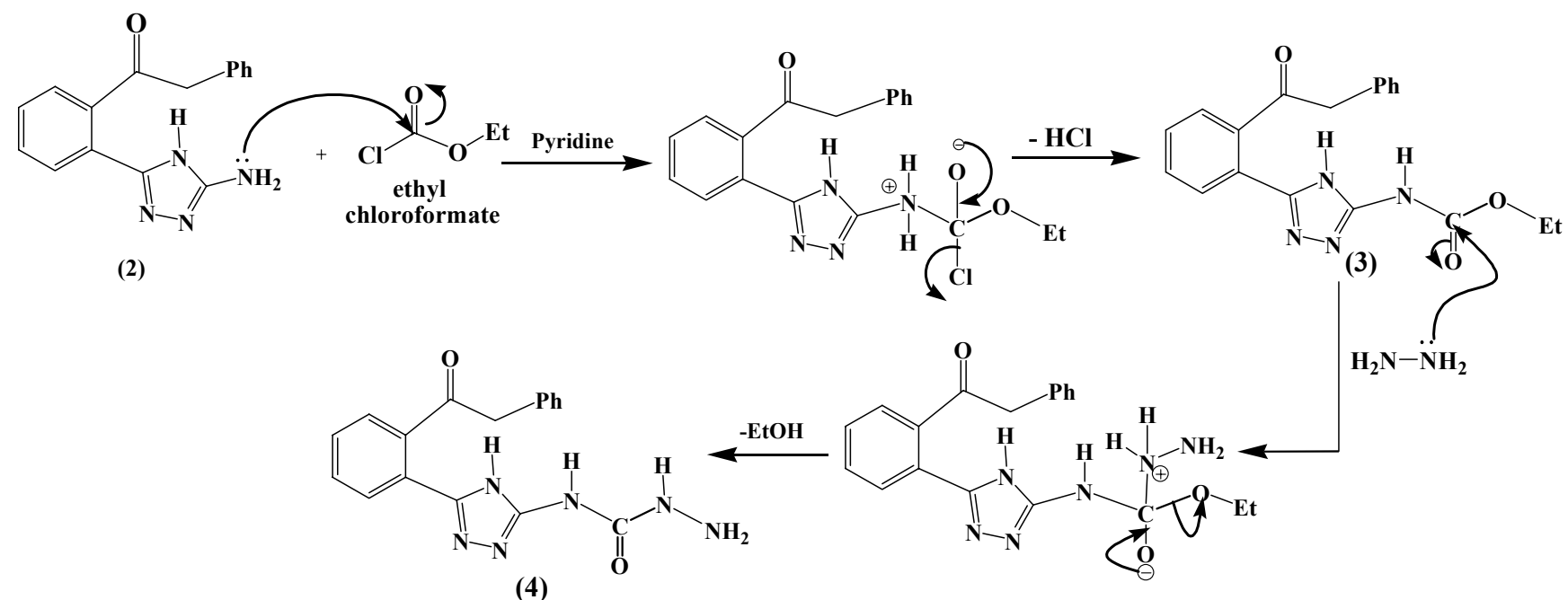

Scheme (4)

The spectral analysis represented by (IR and UV) spectra support the proposed structures of compounds (3) and (4). The IR spectrum of compound (3) showed absorption bands at (3159 $\left.\mathrm{cm}^{-1}\right),\left(1763 \mathrm{~cm}^{-1}\right),\left(1658 \mathrm{~cm}^{-1}\right)$ and $\left(1608 \mathrm{~cm}^{-1}\right)$ assigned to $(\mathrm{NH}),(\mathrm{C}=\mathrm{O})$ urethane, $(\mathrm{C}=\mathrm{O})$ and $(\mathrm{C}=\mathrm{N})$ bond stretching respectively. While the spectrum of compound (4) showed absorption bands at $\left(3300 \mathrm{~cm}^{-1}\right),\left(3159 \mathrm{~cm}^{-1}\right),\left(1690 \mathrm{~cm}^{-1}\right),\left(1658 \mathrm{~cm}^{-1}\right)$ and $\left(1608 \mathrm{~cm}^{-1}\right)$ assigned to $\left(\mathrm{NH}_{2}\right)$, $(\mathrm{NH}),(\mathrm{C}=\mathrm{O})$ urea, $(\mathrm{C}=\mathrm{O})$ and $(\mathrm{C}=\mathrm{N})$ bond stretching respectively. Moreover, the UV spectrum of compound (3) gave absorption band at $\lambda_{\max }(238 \mathrm{~nm})$ and $(288 \mathrm{~nm})$ related to $\pi \rightarrow \pi^{*}$ and $n \rightarrow \pi^{*}$ transition respectively (Silverstein et al, 1974), whereas the UV spectrum of compound (4) gave absorption band at $\lambda_{\max }(246 \mathrm{~nm})$ and $(274 \mathrm{~nm})$ attributed to the conjugation in the new synthesized system and also to $\pi \rightarrow \pi^{*}$ and $n \rightarrow \pi^{*}$ transition respectively, (Parikh, 1974; Silverstein et al, 1974). The ${ }^{1} \mathrm{H}-\mathrm{NMR}$ measurement of compound (3) showed the following characteristic peaks at $\delta(\mathrm{ppm}): 1.4\left(\mathrm{t}, 3 \mathrm{H}, \mathrm{CH}_{3}\right), 3.4\left(\mathrm{~s}, 2 \mathrm{H}, \mathrm{CH}_{2}\right), 4.5(\mathrm{q}, 2 \mathrm{H}, \mathrm{O}-$ $\mathrm{CH}_{2}$ ), 7.1-8.3 (m,H-aromatic), $8.4(\mathrm{~s}, 1 \mathrm{H}, \mathrm{NH})$ and 13 (NH-triazole), while compound (4) showed absoption peaks at $\delta(\mathrm{ppm}): 3.4\left(\mathrm{~s}, 2 \mathrm{H}, \mathrm{NH}_{2}\right), 4.3\left(\mathrm{~s}, 2 \mathrm{H}, \mathrm{CH}_{2}\right), 6.9(\mathrm{~s}, 1 \mathrm{H}, \mathrm{NH}-\mathrm{urea}), 7.1-$ 8.2 (m,H-aromatic) and 13.2 (s,1H,NH-triazole).

In order to prepare and characterize the final products represented by compounds $(5 \mathrm{a}-\mathrm{f})$, compound (4) can be considered as useful intermediat, it was treated with different substituted benzoic acid in presence of phosphorous oxychloride which act as a chlorinating and dehydrating agent respectively. Mechanistically, it is reasonable to assume that the reaction was proceeded firstly via chlorination of substituted benzoic acid to afford the acid chloride intermediate (I) which upon reaction with compound (4) yielded the semicarbazide intermediate (II). Finally, cyclodehydration of the intermediate (II) takes place in the presnce of 
phosphorous oxychloride yielded the corresponding compounds (5a-f) as shown in scheme (5), (Said, 2006).

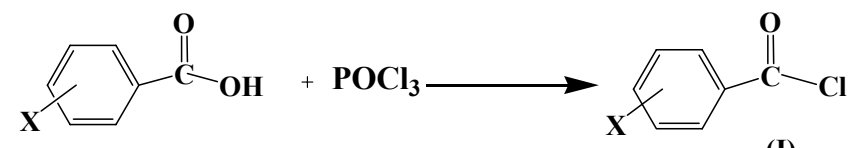

(I)

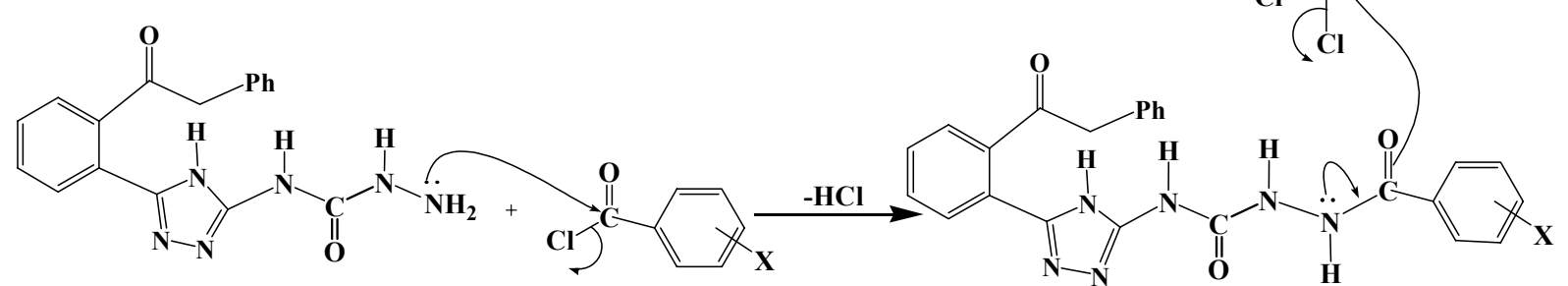

(4)

(II)

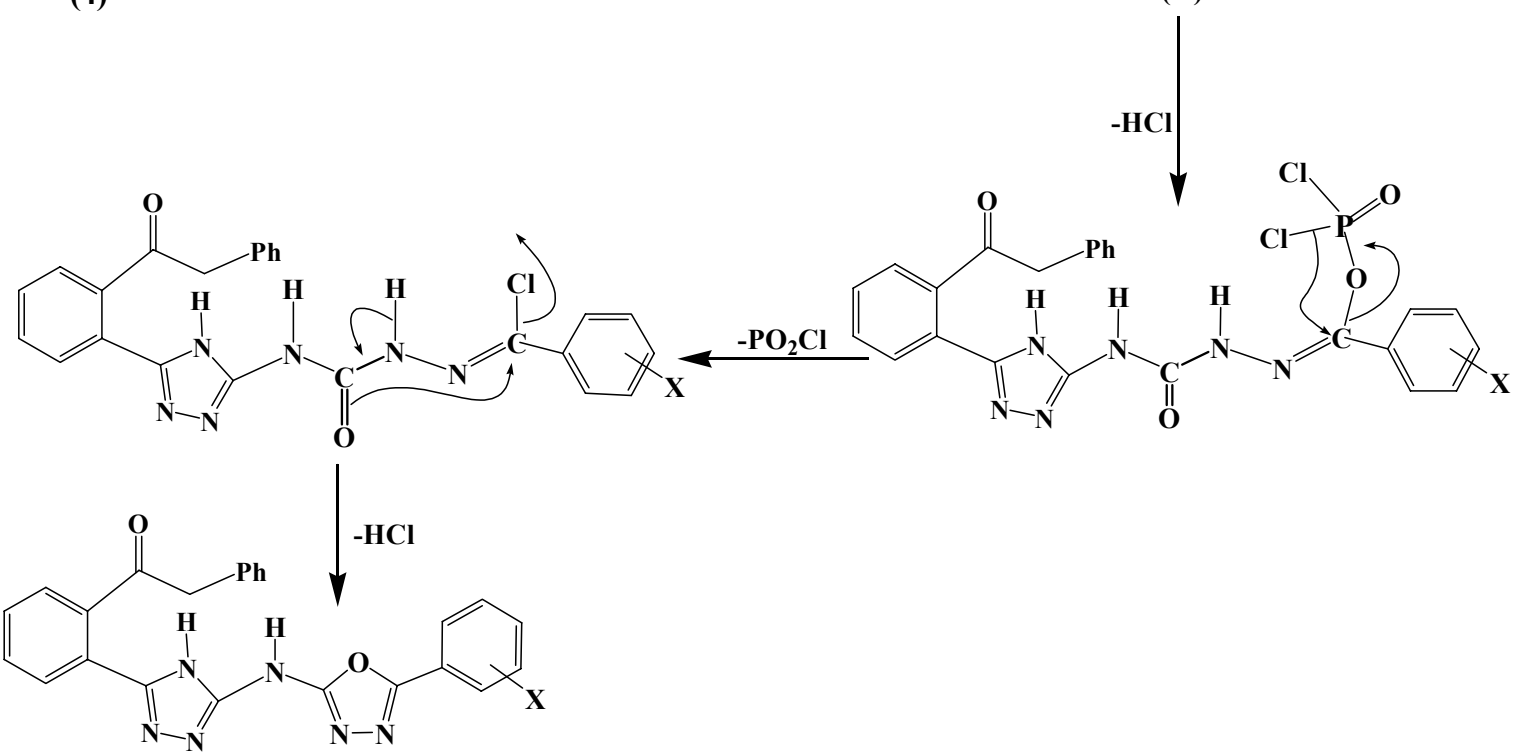

(5a-f)

$\left[\mathrm{X}=\mathrm{H} ; \mathrm{p}-\mathrm{Cl} \quad ; 2,4-\mathrm{diCl} ; \mathrm{o}-\mathrm{NO}_{2} \quad ; \quad \mathrm{m}-\mathrm{NO}_{2} ; \mathrm{p}-\mathrm{NO}_{2}\right]$

\section{Scheme (5)}

The structure of compounds (5a-f) were elucidated in the basis of their spectral data which was came in agreement with the proposed structure, Table (1 and 2). Thus, in IR spectra the absence of bands due to $(\mathrm{C}=\mathrm{O}$ urea $)$ and $\left(\mathrm{NH}_{2}\right)$ bond stretching which are present in the parent compound (4) and the presence of bands due to cyclic (C-O-C) and only (N-H) sharp band at (1166-1180 $\left.\mathrm{cm}^{-1}\right)$ and (3161-3171 $\left.\mathrm{cm}^{-1}\right)$ bond stretching respectively, clearly indicated the 
formation of compounds (5a-f). On the other hand, in UV spectra they showed maximum absorption bands at $\lambda_{\max }(274-282 \mathrm{~nm})$ related to the resonance effect ( Parikh, 1974; Finar, 1977). The ${ }^{1} \mathrm{H}-\mathrm{NMR}$ measurement of compound (5a-c and 5e-f) are in agreement with the proposed structure, Table (2). The proton of 1,2,4-triazole ring appear as singlet peak at (13.2$12.9 \mathrm{ppm})$, whereas the aromatic protons appears as multiplet in the region between (7.1-8.6 ppm). The peaks of the $\mathrm{NH}$ and $\mathrm{CH}_{2}$ protons appear as singlet at (4.9-4.7 ppm) and (4.4-3.4 ppm) respectively.

The purity of the synthesized 1,3,4-oxadiazoles (5a-f) were ascertained by thin layer chromatography (TLC) using (ethyl acetate: acetone) (9:1) ratio as suitable solvent system (Khan et al., 2004). This technique was also used to provide the formation of compounds (5a-f) by comparing it's $\mathrm{R}_{\mathrm{f}}$ values with those of compound (4), Table (1).

\section{REFERENCES}

Al-Mousawi, S. M.; El-Apasery, M. A. (2009). Azolyacetones as precursors to indoles and naphthofurans facilitated by microwave irradiation with simultaneous cooling, Molecules, 14, 2976-2984.

Aly, A.A.; EL-Sayed, R. (2006). Synthesis and biological activity of new 1,3,4-thiadiazole derivatives,Chem. Pap., 60 (1), 56-60.

Aly, A.A.; Brown, A.B.; El-Emary, T.I.; Ewas, A.M.M.; Ramadan, M. (2009). Hydrazine carbothioamide group in the synthesis of heterocycles, ARKIVOC, I, 150-197.

Arulmurugan, S.; Kavitha, H. P. (2010). 2-Methyl-3-\{4-[2-(1H-tetrazol-5-yl)ethylamino] phenyl -3H-quinazolin-4-one, Molbank, M695,1-5.

Awadallah, A.M. (2006). Reaction of aryl- and heteroaryl benzoyl- and acetyl hydrazones with phenylisocynate synthesis of substituted -2,3-dihydro-1,3,4-oxadiazoles, The Islamic University J. (Series of Natural Studies and Engineering), 14(1), 129-133.

Banday, M.R.; Mattoo, R.H.; Rauf, A. (2010). Synthesis, characterization and antibacterial activity of 5-(alkenyl)-2-amino- and 2-(alkenyl)-5-phenyl-1,3,4-oxadiazoles, J. Chem. Sci., 122( 2), 177-182.

Bari, S.B.; Agrawal, A.O.; Patil, U.K. (2008). Synthesis and pharmacological evaluation of some novel isatin derivatives for antimicrobial activity, J. Sci. Islamic Republic of Iran, 19(3), 217-221.

Benjamin, E.; Hijji, Y. (2007). A novel microwave synthesis of unsubstituted cyclic imides, $11^{\text {th }}$ International Electronic Conference on Synthetic Organic Chemistry.

Caiazzo, A.; Dalili, S.; Picard, C.; Sasaki, M.; Siu, T.; Yudin, A.K. (2004). New methods for the synthesis of heterocyclic compounds, Pure Appl. Chem., 76( 3), 603-613.

Chiriac, C.I.; Nechifor, M.; Tanasa, F. (2007). Formamide, a novel challenging reagent for the direct synthesis of non-substituted cyclic imides, Revue Roumaine de Chimie, 52(8- 9), 883-886.

Conner, D.E. (1982). Benzalphthalides and broad spectrum sun screen, U.S. Patent, 4,333,920.

Dalloul, H. M. (2010). Heterocyclic synthesis using nitrilimines: part 14.synthesis of new pyrazole derivatives, Turk J. Chem., 34, 529-535. 
Del olmo, E.; Barboza, B.; Ybarra, M. I.; Lo'pez-Pe'rez, J. L.; Carro'n, R.; Sevilla, M.A.; Bosellid, C.; Felicia, A.S. (2006). Vasorelaxant activity of phthalazinones and related compounds, Bioorganic and Medicinal Chemistry Letters, 16, 2786-2790.

Dewangan, D.; Pandey, A.; Sivakumar, T.; Rajavel, R. (2010). Synthesis of some novel 2,5disubstituted 1,3,4-oxadiazole and its analgesic, anti-inflammatory, anti-bacterial and anti-tubercular activity, International J. Chem. Tech. Research, 2(3), 1397-1412.

Finar, I.L. (1977). "Organic Chemistry". Longman, Vol. 2, pp.17-18.

Ganji, S.H.; Karigar, C.S.; Pujar, B.G. (1993). Metabolism of benzalphthalide by Pseudomonas sp, World Journal of Microbiology and Biotechnology, 9, 597-598.

He, D.; Zhu, Y.; Yang, Z.; Hu, A.; Cao, G. (2009). Synthesis, characterization, and optical properties of novel 2,5-bis[4-(2-(aryl vinyl)phenyl]-1,3,4-oxadiazoles, Turk. Chem., 33, 393-397.

Hrnčiar, P.; Ertl, P.; Hrnčiar, P.; Toma, Š. (1994). Complexation of phthalides and substituted 3-benzylidene phthalides with $\mathrm{Cr}(\mathrm{CO})_{6}$, J. Organometallic Chem., 464 (1), 65-69.

Humber, L.G. (1974). 5-Cycloalkylidene dibenzocycloheptene derivatives, U.S. Patent, 3, 832,405 .

Husain, A.; Ajmal, M. (2009). Synthesis of novel 1,3,4-oxadiazole derivatives and their biological properties, Acta. Pharm., 59, 223-233.

Ibrahim, T.M. (1991). Synthesis of biological active 3- benzylidenephthalide derivatives, Arch. Pham. Res., 14(4), 342-345.

Ilango, K.; Valentina, P.; Umarani, N.; Beena, K.P. (2010). Eco-benign mediated versatile synthesis of newer quinazolin-4- $(3 \mathrm{H})$-one clubbed isatin derivatives as potent antimicro-bial agents, Int. J. Res. Pharm. Sci., 1(2), 133-138.

Jain, N.; Pathak, D.P.; Mishra, P.; Jain, S. (2009). Syntheses and antibacterial studies of some 2-[5-(aryl)-[1,3,4]oxadiazole-2-ylsulfanyl] alkanoic acids, J. Iran. Chem. Soc., 6(1), 77-81.

Kanazawa, C.; Terada, M. (2007). Organic-base-catalyzed synthesis of phthalides via highly regioselective intramolecular cyclization reaction, Tetrahedron Lett., 48(6), 933-935.

Khan, K.M.; Ullaha, Z.; Rania, M.; Perveenb, S.; Haidera, S.M.; Choudharya, M.I.; Rahmana , A.; Voelter, W. (2004). Microwave-assisted synthesis of 2,5-disubstituted-1,3,4oxadiazoles, Letters in Organic Chemistry, 1, 50-52.

Kim, H.S.; Kang, S.M. (2008). Facile synthesis and characterization of poly (dialkoxy-pphenylene-1,3,4-oxadiazole-alt-phenylene-1,3,4-oxadiazoles), Macromolecular Research, 16(4), 360-366.

Kundu, N.G.; Pal, M.; Nandi, B. (1998). Palladium-catalysed heteroannulation with terminal alkynes: synthesis of phthalides, J. Chem. Soc., Perkin Trans., 1, 561-568.

Kurume, A.; Kamata, Y.; Yamashita, M.; Wang, Q.; Matsuda, H.; Yoshikawa, M.; Kawasaki, I.; Ohta, S. (2008). Synthesis of 3-substituted isocoumarins and their inhibitory effects on degranulation of RBL-2H3 cells induced by antigen, Chem. Pharm. Bull., 56(9), 1264- 1269.

Litvan, F.; Stoll, W. (1958). Substituted 2-phenyl indan-1,3-dione, U.S. Patent, 2, 820,738. 
Mayekar, A.N. (2010). Synthesis and antimicrobial studies on new substituted 1,3,4oxadiazole derivatives bearing 6-bromonaphthalene moiety, Int. J. Chem., 2(1), 38-54.

Mitsui, Y.; Aoki, Y. (2010). In vitro effect of current antimalarial drugs on the survival of paired Schistosoma mansoni adult worms and their egg production, Tropical Medicine and Health, 38 (2), 69-73.

Mostafa, T.B. (2010). Synthesis and modification of some heterocyclic compounds with potential biological activity coupled on poly (maleic anhydride -methyl methacrylate), J. Amer. Sci., 6(8), 515-524.

Naik, R.; Naik, H.S.B.; Kumar, H.N.H.; Hosamani, K.M.; Mahadevan, K.M. (2009). Studies on the synthesis and fluorescent properties of long-chained 2-(5-alkyl-1,3,4oxadiazole-2-yl)-3H-benzo[f]chromen-3-ones, ARKIVOC, II, 11-19.

Narasimhan, B.; Kumar, P.; Sharma, D. (2010). Biological activities of hydrazide derivatives in the new millennium, Acta. Pharmaceutica Sciencia , 52, 169-180.

Parikh, V.M. (1974). "Absorption Spectroscopy of Organic Molecules". Edition Wesely Publishing Comp., Inc., 30p.

Patel, N.B.; Patel, J.C. (2010). Synthesis and antimicrobial activity of 3-(1,3,4-oxadiazol-2yl)quinazolin-4(3H)-ones, Sci. Pharm., 78, 171-193.

Patil, S.T.; Karink A.V.(2007). Cascade synthesis of racemic 3-aryl phthalid, Indian J. Chem. 46B, 710-712.

Phan, D.H.T.; Kim, B.; Dong, V. M.( 2009). Phthalides by rhodium-catalyzed ketone hydroacylation, J. Amer. Chem. Soc., 131, 15608-15609.

Revanasiddappa, B.C.; Subrahmanyam, E.V.S. (2010). Synthesis and biological evaluation of 2, 5-disubstituted-1, 3, 4-oxadiazoles, Int. J. Chem. Tech. Res. , 2(2), 1094-1096.

Rios, M.Y.; Delgado, G. (1999). Lewis acid catalyzed transformations Z-ligustilide, J. Mexican Chem. Soc., 43(3,4), 127-32.

Rosenthal, A.; Yalpani, M. (1965). Reaction of aralkyl ketone phenylhydrazones with carbon monoxide; thermal indolization of aralkyl ketone phenylhydrazones, Canadian J. Chem., 43, 3449-3451.

Said, S.A. (2006). Synthesis of some new 2-(2-isopropyl-5-methyl phenoxymethyl)-5-aryl1,3,4-oxadiazoles, Raf. J. Sci., 17(4), 52-58.

Scholl, T.; Serini, V.; Rathmann, D.; Savage, R.; Kircher, K. (1989). Use of 3-benzalphthalide as uv stabilizers for thermoplastic, aromatic polyesters, polycarbonates and polyester carbonates, U.S. Patent, 4,797,435.

Şener, A. (2004). One step synthesis and some reactions of 7-hydrazino-3,4-diphenyl-2Hpyrazolo [3,4-d]pyridazine, Turk. J. Chem., 28, 39 - 45.

Sharma, R.K.; Shrivastava, K.; Daniel, V.; panwar, M. S.; Goyal, S. (2010). Synthesis and anti helmentic activity of some azole derivatives of hippuric acid, Int. J. Pham. Sci., 2(2), 502-507.

Shetgiri, N.P.; Nayak, B.N. (2005). Synthesis and antimicrobial activities of oxadiazoles, phthalazines and indolinones, Indian J. Chem., 44B, 1267-1272.

Shibata, T.; Gaesser, G. (1991). Sensitizer for heat paper coatings, U.S. Patent, 5, 066,633. 
Silverstein, R.M.; Bssler, C.G.; Morril T.C. (1974). " Spectrometric Identification of Organic Compounds ", 3rd edn., John Wiley and Sons, Inc., pp. 246-247.

Srinivas, K.; Kumar, K.P. (2010). Synthesis, antimicrobial and antihelmintic activity of 1-[(5substituted-1,3,4-oxadiazole-2-yl)methyl]-4-propylpiperazines, International J. Biopharmaceu., 1, 14-19.

Tang, Y.; Zhu, M.; Yu, S.; Hua, Y.; Duan, J.; Su, S.; Zhang, X.; Lu, Y.; Ding, A. ( 2010). Identification and comparative quantification of bio-active palides in essential oils from si-wu-tang, fo-shou-san, radix angelica and rhizoma chuanxiong, Molecules, 15, 341-351.

Viña, D. ; del Olmo, E.; Lopez-Pérez, J. L.; Feliciano, A.S. (2008). Pyrazolo[3,4,5-de] phal-azine. Syntheses of a practically unknown heterocyclic system, Tetrahedron, $\mathbf{6 5}(8)$, 1574-1580.

Youssef, A.S.A. (2006). Reactions of 3-substituted-5-arylmethylene-1,3-thiazolidin-2,4diones with azide and cyanide ions, World J. Chem., 1 (1), 10-19. 